\title{
Window design selection and energy consumption implications for residential buildings in Ghana: A behavior- change analysis of Ga East and Awutu Senya East Municipalities
}

\author{
Simon Bawakyillenuo * \\ Innocent Sefadzi Komla Agbelie
}

\begin{abstract}
The challenge of reducing carbon emissions for the purpose of climate change mitigation requires both supply-side and demand-side energy efficiency measures. On the demand side, buildings worldwide account for about 30-40\% of the total energy demand, thereby forming the largest sectoral consumer of electricity. Hence, the building sector offers a great opportunity for energy conservation and efficiency drives if certain behavioural patterns were to change. An important element of the building, which often influences energy consumption, is the design of the window. This paper investigates the economic, energy efficiency and sociological dimensions of the shift from traditional window designs to alternative ones in Ghana. Through quantitative and qualitative analyses of the data gathered for the 2014 Energy Surveys in the Ga East and Awutu Senya East Municipalities in Ghana, most homeowners use new window designs predominantly for aesthetic reasons. While more wooden and louvre blades windows users depend heavily on natural ventilation systems, glazed windows users depend mostly on fans and air conditioners. Consequently, glazed windows users spend more money on electricity compared to users of other window types. These findings manifest the energy inefficiency of most recent architectural designs in Ghana and, therefore call for appropriate policy interventions.
\end{abstract}

Keywords: Windows; traditional; glazed; energy; efficiency

Institute of Statistical, Social and Economic Research, University of Ghana, Legon. *Corresponding author's mail: sbawakyillenuo@ug.edu.gh

Ghana Journal of Geography Vol. 12 (2), 2020 pages 25- 61

https://dx.doi.org/10.4314/gjg.v12i2.2 


\section{Background and Introduction}

The survival of the human race depends upon the survival of our cities-their built environment and the urban infrastructure (Ali, 2008). With the advancement of technology, building materials and architectural designs of both residential and commercial buildings have evolved over time globally, assuming different shapes and complexities. Different architectural designs are critical to suit different climatic conditions. Hence, an adoption of architectural designs, which are inappropriate for certain climatic conditions, will have social, economic and environmental consequences. In developing countries such as Ghana, building designs have begun to assume various degrees of complexity because of the quest for development. Development in these countries is synonymous with tall commercial buildings (skyscrapers) and complex residential mansions or houses in general embodying glazed sliding windows and doors. Lately, these architectural designs are ubiquitous in urban Ghana with several upcoming buildings assuming similar designs, while old window designs such as wooden traditional windows and louvre blades are less utilised. Paradoxically, the umpteenth uses of glazing materials have suddenly become the yardstick by which good designs are measured.

Energy consumption in the developing world has grown tremendously over the past years. This is attributed to increasing urbanization in the region, particularly in areas where the rise in income has resulted in greater demand for transportation and home appliances especially, space conditioning appliances (UN-HABITAT, 2016). Buildings in developing countries account for over $80 \%$ of the total electricity consumption mainly through conditioning the air inside and lighting inside and around the buildings (REN21, 2014). In Ghana, buildings consume between $40 \%$ and $50 \%$ of the total energy use through lighting, ventilation and air conditioning and powering of household electrical fittings (Nsakie-Kassim, 2010). The lighting and cooling needs of a typical modern urban building in Ghana (be it a commercial skyscraper office building or a residential mansion) could be as much as the entire electricity consumption of some rural villages. Since Ghana has one of the highest electricity tariffs in the sub-region (USD 0.063 and USD 0.136 for households and businesses respectively) according to AfDBERERA (2019), uncontrolled electricity consumption in buildings, especially in the urban cities, could create electricity triggered expenditure burdens on the occupants. This could also exacerbate the already increasing emission of $\mathrm{CO}_{2}$ in the country. The World Energy Council 
Window design selection and energy consumption implications for residential buildings in Ghana: A behavior-change analysis of Ga East and Awutu Senya East Municipalities

(WEC) (2013) note that total energy use of a building can be reduced by implementing energy efficient design strategies at the design stage. It therefore implies that marginal energy savings across all buildings can have a profound contribution to carbon mitigation.

Using both quantitative and qualitative methods, this paper investigates the economic and energy efficiency dimensions of the shift from traditional window designs to the new window designs in Ghana. We explore the main factor (s) underpinning such a shift. It interrogates whether the new window designs could be influencing higher electricity spending by occupants of such buildings in Ghana and vice versa. Findings from the paper could be critical for ascertaining the pathways that are needed in order to enhance energy efficiency and conservation in residential buildings. The paper is organized in six sections. Following the introductory section is the second section, which discusses the contextual issues, empirical and theoretical literature. The third section presents the evolution of buildings, windows and general building regulations in Ghana. The fourth section discusses the methodology and study areas, followed by discussion of the empirical results in section five. The final section provides conclusion to the study with policy implications of the findings.

\section{The evolution of windows, building regulations and energy systems in Ghana}

\section{Evolution of building and window designs in Ghana}

There is no established pattern, philosophy or style for designing buildings in Ghana. Old building designs are often a reflection of Ghanaian traditional heritage. New building designs are however, more foreign; reflecting the owners' taste and choice. The Ghanaian architectural landscape has witnessed varied architectural developments through influences from within and outside of the country. Elleh (1996) regards African architecture, and for that matter Ghanaian architecture as a triple heritage of indigenous architecture, Islamic and Western architectures. Ghanaian architecture was predominantly traditional before the encounter with the Arabians and later, Europeans through trade and colonization respectively.

Traditional Ghanaian architecture can be identified with three geographical zones namely, the northern, middle and southern zones of the country. In the northern zone, traditional building methods with red soil mud are still practiced, especially in the rural areas (Schreckenbach, 
1981). The middle zone architecture consists of wattle and daub methods constructed with gables and supported by timber poles of bamboo. The roofs are often made of woven thatch of palm leaves (Swithenbank, 1969). In the southern zone the traditional buildings are made up of wattle and daub construction, walls of stone or what is also known as 'atakpame' method, sun-dried bricks from laterite soils and burnt bricks. European style buildings started gaining influence in Ashante and Fante villages as well as Akwapim area in Eastern region in which buildings were constructed of stone and roofed with shingles (Schreckenbach, 1981).

By virtue of her location, Ghana experiences high temperatures, and hence requires cooling systems in dwelling units in order to enhance thermal comforts. In this regard, the type(s) of window designs of dwelling units are as important as the building itself, in facilitating the cooling of the rooms or increasing the temperature in the rooms. The coastal enclaves of Ghana enjoy free flowing sea breeze all year round, hence architects are presumably mindful of this natural gift when designing different components of buildings like the windows. The traditional dwelling units and the early European building styles used in the post-independence period used predominantly, single or double wooden windows (see Plate 1A). These windows were usually opened to allow in fresh air for ventilation and sunlight to brighten the rooms during the daytime. In the post-independence era, the wooden window system was gradually being substituted with the louvre blade window system (see Plate 1B). Many homes and offices replaced their wooden windows with louvre blades while new buildings adopted the new glazed window design. Two types of the louvre blade windows were used: the wooden louvres and the glass with aluminum frame louvres (see Plate 1C). Whether they are made of wood or glass, these louvres are usually tilted to allow airflow in and out of the room.

The speedy rate of penetration of this window system was reinforced by the Government of Ghana's quest for energy conservation, through workshops organized under the Energy Efficiency and Conservation Programme in the 1980s and 1990s. One measure that was encouraged under the programme was the adoption of louvre blades in contrast with its wooden predecessor that insulated rooms to high temperatures.

From the early 2000s, a paradigm shift started with respect to the window system being used in buildings in Ghana: glazed windows (see Plate 1D). The roots of these glazed windows are traced to Europe and other temperate regions. Glazing windows fall into three categories: single, double and triple glazing. The process involves mounting glass on the surface of a 
Window design selection and energy consumption implications for residential buildings in Ghana: A behavior-change analysis of Ga East and Awutu Senya East Municipalities

window sash or door stile. Glazed windows (especially the single glazing) have predominated buildings in the formal commercial sector and residential settings (especially in major cities) in Ghana. 
Ghana Journal of Geography Vol. 12 (2), 2020 pages 25- 61

Plate 1: Different window types in Ghana (ASEM and GEM)

A. Fixed metal with net shield windows (non-operable)

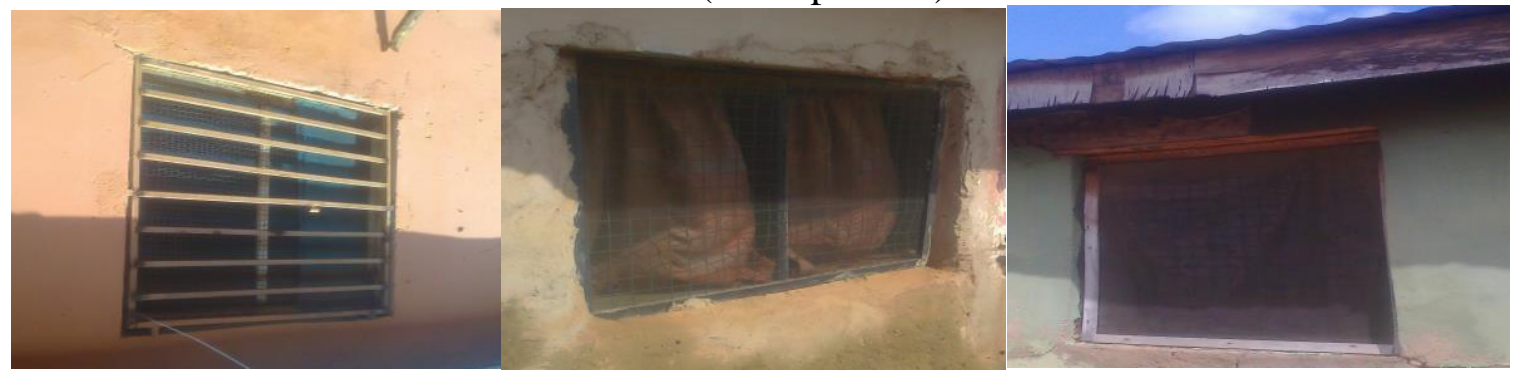

B. Traditional operable wooden windows

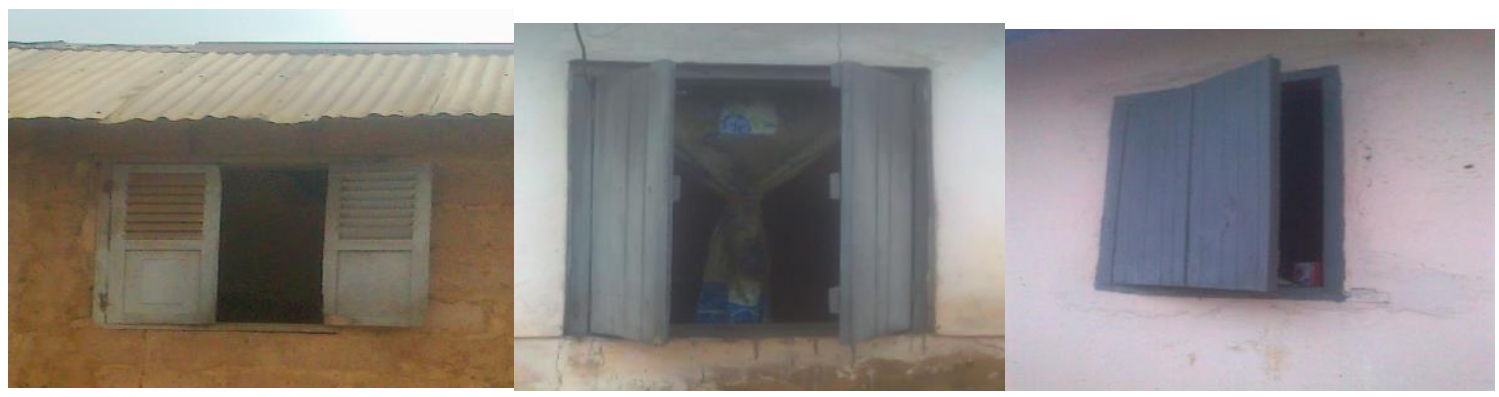

C. Operable louvre blade Windows

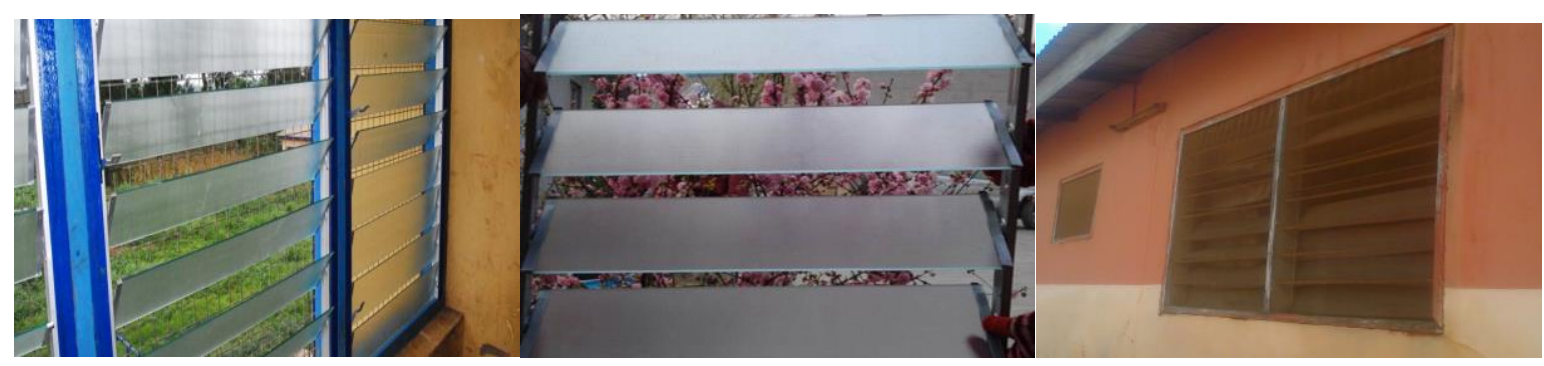

D. Operable glazed windows

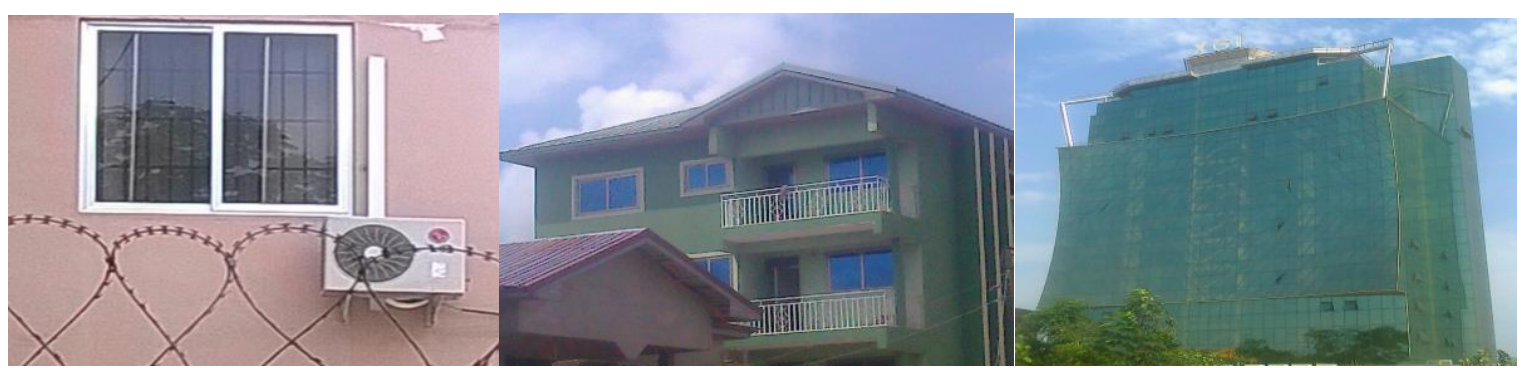

Source: Authors' and Google Images 
Window design selection and energy consumption implications for residential buildings in Ghana: A behavior-change analysis of Ga East and Awutu Senya East Municipalities

\section{Landscape of the existing National Building Regulations in Ghana}

Building codes and regulations are prescriptive and performance related provisions for building systems legislated and enforced by a national authority. They govern specific jurisdictions and embody the legal framework and mandates for ensuring the benefits, welfare and conveniences to all persons in relation to all building processes. Though they are targeted at a unique geopolitical jurisdiction, they have evolved over the years to align with global best practices (CASA ASSSOCIATI, 2012).

The building code regime of the Republic of Ghana is governed by the National Building Regulation Legislative Instrument LI 1630 (1996) derived out of Act 462 of the Local Government Act of 1993. The core principle of Ghana's National Building Regulation just like most national codes is the provision of guidelines for safety, health and governance. Its administration is the responsibility of the Local Government authorities at the various levels: Metropolitan, Municipal and District Assemblies (MMDAs).

The national building regulations (NBR) of Ghana make general provisions for the safety of buildings and occupants. Segments 2, 4, 8 and 9of the NBR makes provisions for location and spatial requirements; material composition, ventilation system of buildings and thermal insulation. A notable absent in the NBR of Ghana are climate compatible provisions to mitigate the effects of climate change and climate variability. Importantly, the NBR lacks provisions on the specific types of window materials appropriate for Ghana as a tropical country to make buildings more "green". Added to this is the absence of specifications in the NBR regarding how natural ventilation, air movement and cross ventilation should be enforced.

\section{Electricity systems in Ghana}

The energy landscape of Ghana, in terms of the final energy consumed, is dominated by petroleum products (47.6\%), biomass (37.4\%) and electricity (15\%) as of 2019 (Energy Commission, 2020). The dominant electric power end uses in buildings in Ghana are lighting, refrigeration and space cooling. Various sources of lighting include electricity, kerosene lamp, gas lamp, solar energy, candles and torches. According to the report of the seventh round of 
the Ghana Living Standard Survey, the national grid is the predominant source of lighting for most households in Ghana (GSS, 2019).

Similarly, electricity is the main source of power for ventilation and air conditioning (VAC), entertainment and ironing end uses in Ghana. The total grid electricity generated increased from 16,246 GWh in 2018 to $18,267 \mathrm{GWh}$ in 2019. Meanwhile, the total grid electricity consumed also increased marginally from 13,185 GWh in 2018 to $13,943 \mathrm{GWh}$ in 2019 (Energy Commission, 2020). The trend of grid electricity generation reveals an increasing thermal power generation in the energy mix and a decreasing composition of hydropower generation. In 2013, the shares of grid electricity generation by plant are as follows; hydro plant $-64 \%$, thermal plants $-36 \%$ and renewables $-0.02 \%$. In 2016, the shares include hydro plant $-42.7 \%$, thermal plants $-57.1 \%$ and renewables $-0.2 \%$. By the end of 2019 , chunk of our grid electricity is generated from thermal plants (59.8\%) followed by hydro plants (39.9\%) and renewables (0.3\%) (Energy Commission, 2020).

The increase in total power installed capacity, and in particular thermal capacity is a conscious response by government to the latest power crisis that hit the country between 2012 and 2017 . This was attributed to the shortfall in supply largely blamed on low water level in the Akosombo, Kpong and Bui Dams on which the hydro plants are built, as well as issues related to shortages in gas supplies to power the plants. Though the share of renewables also increased insignificantly from $0.02 \%$ in 2013 to $0.2 \%$ in 2017 , it completely missed government's target of $10 \%$ in Ghana's energy mix by 2015 . The period of the power crisis also saw an upsurge in the use of private diesel/petrol powered generators to produce electricity, especially by commercial ventures and affluent households. This has cost implications on the economy. Abeberese, Ackah and Asuming (2017) found a 10\% reduction in the monthly productivity of firms in Ghana because of the 2012-2016 power crises.

An energy survey carried out in 2014 in Awutu Senya East Municipality (ASEM) and Ga East Municipality (GEM) in Ghana revealed that the household, commercial, industrial, agriculture and the Municipal Assemblies are the energy intensive sectors in the municipalities. In ASEM, the total energy consumed by these sectors as of 2013 came to almost 5 million Gigajoules with the majority coming from the transport sector (68\%) followed by household (16\%) and commercial (13\%) (Bawakyillenuo \& Agbelie, 2015). Petrol and diesel are the most consumed 
Window design selection and energy consumption implications for residential buildings in Ghana: A behavior-change analysis of Ga East and Awutu Senya East Municipalities

fuel types in ASEM followed by charcoal and electricity for various end uses including lighting, cooking and transportation. Similarly, in GEM, all the energy demand sectors consumed 9.5million GJ of energy as of 2013 with majority consumed by the transport and household sectors. Diesel, petrol and electricity are the most consumed fuel types for different end uses including transportation, lighting, cooling and cooking (Bawakyillenuo \& Agbelie, 2015).

\section{Context, empirical literature and theoretical framework}

\section{Contextualizing energy efficiency in the built environment}

In the advent of climate change and its devastating environmental and economic effects on the planet earth, not only has environmental awareness intensified in the urban environment, which currently houses nearly $56 \%$ of the world's population (World Bank, 2019), but it has also extended to the built environment, which is a significant consumer of final energy. The reduction of carbon emissions to mitigate climate change requires both supply-side and demand-side energy efficiency and conservation initiatives. On the demand side according to a report by the International Energy Agency (IEA), buildings and construction sector accounts for $36 \%$ of the global final energy use in 2018 and $39 \%$ energy related $\mathrm{CO}_{2}$ emissions in the same year (IEA, 2019a; 2019b). The UK Department of Trade and Industry (2003) observed that "energy is often wasted because of poorly insulated buildings or where heating, ventilation, air-conditioning and lighting are poorly controlled" (p.32).

With rapid population growth coupled with increasing urbanisation rate (3.5\% per year), the energy demand of buildings in Africa is projected to rise throughout (REN21, 2014). At the same time, the building sector offers the largest, most cost-effective opportunities for the enhancement of energy efficiency measures in the continent. Buildings in Africa, like elsewhere, contain an array of energy consuming products in their operational phase (WBCSD, 2009). These are often categorized into lighting, heating and cooling, refrigeration, and electrical equipment. Thus, well-designed, constructed and operated buildings have the potential to reduce energy use significantly. The position of a building, which is whether on a high or low altitude, against or along the direction of the wind influences energy consumption of that facility. 
An important element of the building structure --of interest in this paper--, which often has a significant effect on energy consumption, is the window type of the building. Windows, which connect the inside and outside parts of the buildings, fulfill other homes' several tasks in terms of architectural and environmental needs. Whereas roofs and walls provide heat and moisture impermeability, windows allow air, heat and light transmission. Windows also provide security and protection against unfavourable weather, noise, pollution, insects etc. In terms of energy efficiency and building economy, window design and the selection of an appropriate glazing system are significant (Muneer et al., 2000).

The design or layout of a building does not independently determine energy demand but through the behavioral change of building dwellers. Due to temperature variability, building occupants have adopted advanced modern technologies to condition the air in the buildings in order to make them more habitable. Behavioural change is well documented as a cause of highenergy consumption in buildings. The concept of "comfort" has evolved in the past decades in an era of cheap energy (Kelly, 2010). In temperate regions where room heating is a common practice, one room used to be heated at a time in the past. Presently, more than one room is routinely heated in those regions (ibid). Comfort is subjective and varies from individuals, cultures and sometimes, locations. Different building designs are adopted at different places due to a perceived 'comfort' to be derived.

\section{Review of studies on architectural designs vis-à-vis energy efficiency}

Several scholars have researched on buildings and energy efficiency, especially, in the developed world. These studies are reviewed based on their orientation; scientific experimentation and engineering orientation involving different building technologies or architectural designs that improve energy efficiency in buildings; energy efficiency measuring and rating systems as well as EE standards in buildings; and sociological orientation of EE buildings.

Gyimah and Tetlow (2014) assert that the built environment is a major contributor to climate change since its construction process, material use and even the daily operation uses a lot of energy. Using a comparative analysis between original buildings and case study buildings, the study finds reflection to be key to achieving both aesthetics and energy efficiency in buildings. 
Window design selection and energy consumption implications for residential buildings in Ghana: A behavior-change analysis of Ga East and Awutu Senya East Municipalities

Jelle et al. (2012) argue that vacuum glazing, smart windows, solar cell glazing, window frames, self-cleaning glazing, low-emissivity coatings and spacers represent possibilities for controlling and harvesting the solar radiation energy and making buildings more energy efficient.

Granzotto et al. (2017) performed an in-depth analysis of more than 45 different frame windows comparing thermal and acoustical insulation. The thermal insulation analysis demonstrated that no single windows component could influence final performance but rather, all constituents contribute towards final insulation effect. In an earlier energy and environmental investigation performed on a sample of wooden window selected as a case study in Italy by Baldinelli et al. (2014), the improvement of the window thermal characteristics obtained via proper solar radiation control, is the most relevant criterion to optimize the overall energy and environmental performance of the window in temperate climates.

In an earlier study, Baker et al. (2010) explored means of achieving energy efficiency and concluded that, good thermal performance of traditional windows can be achieved using lowcost methods. Maçka and Yaşar (2011) also investigated the energy efficiency effects of double-glazing window alternative units. Having selected different building models from Ankara in Climate Region III of Turkey for their study, the results reveal that in terms of energy and economic efficiency, smart glazing units and LECLR $2^{5}$ should be preferred in Ankara, with cold climate, for long-term investments, as opposed to $\mathrm{CLR}^{6}$ (the existing glazing unit).

Laban and Folić (2014) evaluates the thermal properties of existing residential buildings, built in industrial manner in Novi Sad, Serbia, from 1960 to 1990 taking into account the building typology. Based on the most common energy rehabilitation measures applied in Serbia, the estimates indicate that it is possible to reduce the energy losses in heating up to $60 \%$ by installing windows of class $\mathrm{A}^{7}$ energy efficiency in combination with the required extra thermal insulation. This finding agrees with the earlier studies of Raloff (1988) and Kelly (2010), which

\footnotetext{
${ }^{5} 6 \mathrm{~mm}$ Low-E glass \#2 $+12 \mathrm{~mm}$ air space $+6 \mathrm{~mm}$ clear glass

${ }^{6} 6 \mathrm{~mm}$ clear glass $+12 \mathrm{~mm}$ air space $+6 \mathrm{~mm}$ clear glass

${ }^{7}$ Window with thermal transmittance coefficient $\mathrm{Uw}=0.73 \mathrm{~W} / \mathrm{m}^{2} \mathrm{~K}$
} 
concluded that materials of much greater thermal insulation (per unit thickness) with accompanying mechanical and stability properties, ease of application to both the interior and exterior walls of buildings, including floors significantly reduce the energy loss in heating.

Armstrong and Burrows (2008) also summarised the results of experiments conducted at the Canadian Centre for Housing Technology (CCHT) comparing the whole house performance of two types of low-emissivity glazing. Accordingly, for the heating-dominated locations that typify Canada, the most energy-efficient window is the high solar heat gain (HSG) windows. They are particularly good in locations where there is exposure to winter sunshine with the use of shades to limit solar heat gain in the summer while glazing with a high insulating value (low U-factor) should be used to minimise conductive heat loss in winter in the north side of a residence. Other studies further echoed that, glass specifications, framing types, geometrical configurations and components like louvered sunshades and light shelves may all be chosen to optimize the amount of thermal energy and natural light a building receives from the sun (Silverstein, 2007; Hermes, 2006; Parasonis et al., 2011).

\section{Review of studies on behaviour and energy efficiency (EE) in buildings}

Behavioural change is very crucial in energy efficiency issues in building operations. This set of empirical literature focuses on behavioural energy practices by building occupants. It is worth noting that, evidence on the effects of behavioural practices of the use of building or parts of the building on energy efficiency is scanty in the energy efficiency in building literature, especially in the developing world.

Dating back to the 1980s, Kantrowitz (1984) argues that buildings which conserve energy through environmental responsiveness can be best tuned and fine-tuned by the people who inhabit those buildings. Occupants understand changes in building operation and use patterns, and often quickly recognize potential comfort problems. Through providing a range of opportunities for occupants to adjust building functions, designers can support competent building users. Based on quantitative surveys and semi-structured interviews with present and potential users of low energy buildings, designers, planners, and manufacturers in Austria, Rohracher and Ornetzeder (2002) support the findings of Kantrowitz(1984) as they argue that 
Window design selection and energy consumption implications for residential buildings in Ghana: A behavior-change analysis of Ga East and Awutu Senya East Municipalities

the introduction of low-energy house technologies will be more successful, if it is organised as a mutual learning process of component producers and users.

The need for such social interaction is demonstrated by recent studies on building and energy efficiency. Guy (2002) notes that understanding of green building requires that people are sensitive not only to the widely differing motivations and commitments of actors, but also to the range of techniques employed, the variety of contexts and settings in which development occurs, and the social processes involved in the definition and redefinition of the nature of the environmental problem itself. Leaman and Bordass (2007) also explored various sources of building occupants' dissatisfaction in the United Kingdom. The study found that green buildings are in danger of repeating past mistakes, especially if they are too difficult to manage such that users tend to tolerate deficiencies more than they do with more conventional buildings.

Additionally, Schnieders and Hermelink's (2006) study of the Kassel project found people's weak response to the initial low energy demand characteristics advertisement but responded greatly after characteristics such as attractive locations and balcony were included in the advertisement. Heerwagen and Zagreus (2005), who investigated user evaluation of Philip Merril Environmental Center in Maryland, U.S reported that some users believe energy efficient buildings can have positive impact on well-being and daily performance.

Koranteng (2010) investigated the energy performance of office building using simulation models on five existing buildings in Kumasi, Ghana. The results demonstrate that some improvements to the building fabric and controls bring about better energy performance of the building. Crucially, improvement measures like efficient windows -with better shading coefficient - and electrical lighting, natural ventilation and attic insulation could reduce cooling loads by 25 to $45 \%$ in Kumasi, Ghana. Having control over these elements, to regulate their use and ensure efficient materials in their installations reduces energy cost of buildings. In a similar study, Gouws et al. (2012) showed that EE correlates with organizational success after they have surveyed 34 respondents from 10 industrial activities in South Africa. They found that $70 \%$ of the surveyed firms engage in energy consumption strategies in their day-today operations. Some EE practices undertaken were "retrofitting of equipment, planting automation and control, training on human intervention and behaviour" (p.8). 
In support of the above findings, Fatoki (2019) found many small and medium-scale enterprises (SMEs) to be using different EE practices in their structures based on 182 sampled immigrant small business owners in South Africa. The trend is similar among large businesses in the country (South Africa) as reported in the study of Dippenaar (2018). Agyeiwaah (2019) also explored the relevance of sustainability practices like using energy-efficient refrigerators, switching off electrical appliances when not in use and the use of energy-efficient lighting bulbs to micro tourism and hospitality accommodation enterprises in Cape Coast, Ghana. The researcher observed that home-stay owners were much concerned about the amount of energy they consumed, hence, entreated customers to abide by energy conservation rules like switching off lighting bulbs when they are going out.

To conclude, evidence from the reviewed literature points to the fact that different climatic regions require distinct $\mathrm{EE}$ designs and orientations as no single EE mechanism can be efficient in all climatic regions. Studies on the behavioural responses of building users towards achieving EE in building are, however, few. This study therefore seeks to add to this stream of literature by investigating the behavioral and energy efficiency issues surrounding the shift from traditional windows to new window designs in Ghana.

\section{Theoretical frameworks of sustainable buildings and energy efficiency}

The discourse on sustainable building and energy efficiency is often discussed in three strands of arguments: technical, behavioural and urban planning (Gestring et al., 1997). Technical strategy focuses on the use of environmentally friendly materials, thermal insulation of buildings, energy efficient heating and lighting, and balanced ventilation systems. Architects, planners and energy experts often profess that this strategy is the most favoured one. For example, better insulation of a building significantly improves its environmental performance without affecting the use of the building and consequently without needing the cooperation of users after the technology has been implemented. Krioukov et al. (2011), however, argue that automated solutions have been shown to be effective in energy conservation efforts, though sometimes at the expense of occupants' comfort. Urban planning strategies are often separated from activities focusing on sustainable buildings, which tend to deal with buildings in isolation from their urban and local context. 
Window design selection and energy consumption implications for residential buildings in Ghana: A behavior-change analysis of Ga East and Awutu Senya East Municipalities

The third dimension, social strategy, puts its main emphasis on the behaviour of users; for example, lowering temperature in rooms not often used or not used overnight, avoiding waste, using public transport, and buying energy efficient refrigerators. Many educational efforts and information strategies target attitudes of users and aim at behavioural changes. However, as it often turns out, even if one manages to raise environmental consciousness, the links between attitude and behaviour are rather weak and depend on various contextual factors (Kempton et al., 1992).

This study focusses on the behavioural pillar of sustainable buildings and energy efficiency model since the preference for a particular window type and energy appliances used in dwelling units are often determined by individual behavioural preferences. Bandura (1986)'s social cognitive theory argues that people are driven not by inner forces, but by external factors ' $\mathrm{k}$ '. The theory suggests that human functioning can be explained by a triadic interaction of behavior, personal and environmental factors as shown in Figure 1 below.

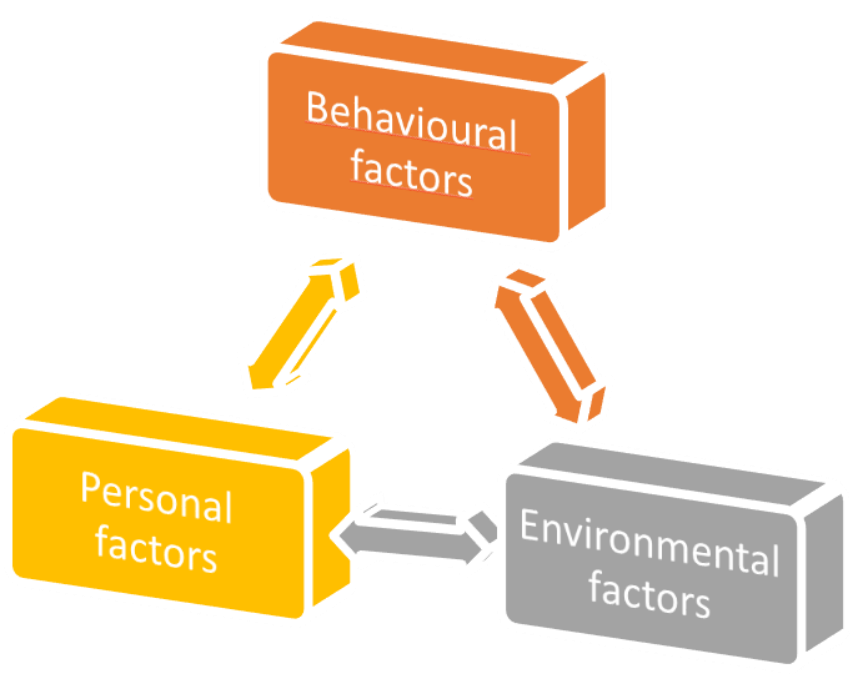

Figure 1: Social Cognitive Theory Model

Source: Bandura, 1986

Environmental factors represent situational influences and environment in which behavior is preformed while personal factors include instincts, drives, traits, and other individual motivational forces. The theory is often known as reciprocal determinism because each factor affects each of the others. For example, an individual's thoughts (self-efficacy) affect his/her behaviour and an individual's characteristics elicit certain responses from the social 
environment. Likewise, an individual's environment affects the development of personal characteristics as well as the person's behaviour, and an individual's behaviour may change their environment as well as the way the individual thinks or feels. The study therefore postulates that, an individual's decision or behavior of adopting a particular window type and use of certain ventilation systems in the dwelling units are determined by the social environment and other personal factors.

Environmental competence and learned helplessness theories are two theories developed in relation to issues of user involvement in building energy management. The environmental competence theory relates to one's perceived ability to understand and negotiate the environment in a meaningful way. The learned helplessness theory, originally developed by Seligman (1975), refers to one's reactions to a situation he/she is inevitably confronted with. The relationship between the two is that if one has learned to be helpless in the built environment because of lack of control, it is difficult to develop and maintain a sense of environmental competence. In instances where opportunities for meaningful interaction with building energy systems are few, a feeling of helplessness can set in. In other words, where those opportunities exist and building users take full advantage of the existence, they become environmentally competent vice versa.

These two theories provide the theoretical landscape of the paper. People may be influenced by the environmental situations around them to use certain facilities, materials or gadgets in the buildings (Social Cognitive theory) while others may have become environmentally incompetent because they do not recognize the opportunities in their built environments (Environmental competence and learned helplessness theories).

\section{Study areas and methodology}

\section{The study areas}

The areas selected for the study include the Ga East Municipality (GEM) in the Greater Accra Region of Ghana and Awutu Senya East Municipality (ASEM) in the Central Region of Ghana 
Window design selection and energy consumption implications for residential buildings in Ghana: A behavior-change analysis of Ga East and Awutu Senya East Municipalities

. These municipalities are partner municipalities on the SAMSET ${ }^{8}$ project in Ghana, and are characterized with rapidly urbanized population, socio-economic problems like insufficient electricity supply in the face of growing electricity consuming sectors, unsustainable waste management practices and poor sanitation. GEM, which covers a land area of 85.7 square kilometers, is one of the sixteen districts in the Greater Accra Region and has a population of about 147,742 with $82 \%$ living in urban areas (GSS, 2014b). ASEM is one of the twenty districts in the Central Region with a landmass of about 108 square kilometers. It has a population size of around 108,422, with an annual growth rate of 3\% (GSS, 2014a). Only 15\% of the population lives in rural areas of the municipality (ibid). Due to its strategic location, rural-urban and urban-urban migration is common in the municipality.

\section{The study designs and sampling frame}

The study employs a mixed method of quantitative and qualitative approaches for data gathering and analysis. The quantitative analysis is based on the quantitative data collected on households in GEM and ASEM for the ISSER State of Energy (SoE) surveys in ASEM and GEM in 2014. While these surveys were conducted on all energy demand and supply sectors in GEM and ASEM, of importance to this study are the household data that were collected in various classes of settlements in the two municipalities.

Households in GEM and ASEM are categorised into three (3) classes: first, second and third classes by the two Municipal Assemblies. The purpose of these classifications is to ensure equitable and effective property and commercial activity revenue collections, because the demarcations are done based on the availability and access to certain basic facilities, infrastructure and utilities. First class settlements benefit from more improved facilities such as good roads, schools, potable water, and wider electricity coverage, hence, businesses and properties in these settlements attract highest fees. Third class settlements have the least facilities, poor roads; low electricity coverage, inadequate potable water, hence, properties and

\footnotetext{
${ }^{8}$ SAMSET was a four-year project $(2013$ - 2017) funded by the EPSRC and DFID and being jointly ran by the Institute of Statistical, Social and Economic Research (ISSER), University of Ghana; Uganda Martyrs University; University of Cape Town; Durham University; University College London; Sustainable Energy Africa (SEA) in South Africa and Gamos Ltd, UK. See Website: https://samsetproject.wordpress.com/
} 
businesses in these settlements attract low fees from the assemblies. In this paper, per the characteristics of the various settlements, the paper conceptualises first class and third class settlements in these municipalities as the high and low-income class settlements respectively. The household population of GEM was extracted from the 2010 Population and Housing Census database while a headcount of households in ASEM was undertaken. The total household population figures for both municipalities are shown in Table 1.

The sample sizes were arrived at using a confidence level of $95 \%$ and confidence interval of 4.0 (margin of error) in the formulas (1) and (2) below developed by survey systems.

$$
\begin{aligned}
& s s=\frac{Z^{2} *(p)^{*}(1-p)}{c^{2}} \\
& \text { new } s s=\frac{s s}{1+\frac{s s-1}{p o p n}}
\end{aligned}
$$

Where;

$\mathrm{Z}$ is the $\mathrm{z}$-value for the corresponding confidence level

$\mathrm{p}$ is the percentage picking a choice, expressed as decimal

$\mathrm{c}$ is confidence interval or the margin of error, expressed as decimal

popn is the population

The sample sizes for the two municipalities were distributed across the classes of households as shown in in Table 1. The distribution was done according to the shares of the populations of households in the various classes of settlements to the total populations of households in the municipalities. 
Window design selection and energy consumption implications for residential buildings in Ghana: A behavior-change analysis of Ga East and Awutu Senya East Municipalities

Table 1: Population and sample sizes of households in GEM and ASEM

\begin{tabular}{lllll}
\hline & \multicolumn{2}{c}{ Awutu Senya East } & \multicolumn{2}{c}{ Ga East } \\
\hline Total HH & Population & Sample & Population & Sample \\
\hline First Class Household & 43,795 & 593 & 33,949 & 590 \\
\hline Second Class Household & 10,161 & 137 & 28,743 & 500 \\
\hline Third Class Household & 15,057 & 204 & 1,870 & 32 \\
\hline
\end{tabular}

Source: ISSER SoE Survey in ASEM and GEM, 2014

The household samples were further broken down into electrified and non-electrified households based on the electrification coverage in the municipalities According to the district analytical reports produced by Ghana Statistical Service, there is $83 \%$ electricity coverage in ASEM while about 78\% of GEM is also covered in terms of electrification (GSS, 2014a; 2014b). Premised on these electrification rates, appropriate samples were drawn from each settlement class to represent the electrified and non-electrified households (Table 2). In this paper, the concentration is on only the electrified household samples because the focus is on energy efficiency issues with respect to electricity usage. In total, about 953 electrified households from GEM and ASEM were involved in the survey. This includes about 503 first class households, 195 second class households and 255 third class households. Random sampling technique was used, with the initial identification of the first household in a location to start from, and subsequent selection of the fourth household considering the previously selected one.

Table 2: Breakdown of household samples into electrified and non-electrified in GEM and ASEM

\begin{tabular}{lcccccccccc}
\hline & \multicolumn{3}{c}{ First Class HH } & \multicolumn{3}{c}{ Second Class HH } & \multicolumn{3}{c}{ Third Class HH } \\
\hline & $\begin{array}{c}\text { Electrif } \\
\text { ied }\end{array}$ & $\begin{array}{c}\text { Non- } \\
\text { elect. }\end{array}$ & Total & $\begin{array}{c}\text { Electrif } \\
\text { ied }\end{array}$ & $\begin{array}{c}\text { Non- } \\
\text { elect. }\end{array}$ & Total & Electrified & $\begin{array}{c}\text { Non- } \\
\text { elect. }\end{array}$ & Total \\
\hline ASEM & 113 & 24 & 137 & 170 & 34 & 204 & 210 & 42 & 252 \\
\hline GEM & 390 & 110 & 500 & 25 & 7 & 32 & 45 & 13 & 58
\end{tabular}

Source: ISSER SoE Survey in ASEM and GEM, 2014 
Qualitative in-depth and key-informant interviews (IDI and KII) were undertaken in the two municipalities to capture relevant data to supplement the quantitative data. Interview guides were developed in relation to the window types in various dwelling units, social and energy efficiency issues surrounding the use of these different window types. The sampling was purposive and targeted households that use the different window types discussed above. Twelve (12) households that took part in the quantitative energy survey were selected from GEM and ASEM for the in-depth and key-informant interviews. These 12 households consisted of 6 glazed window users, 2 louvre blades window users, 2 wooden window users and 2 other window users (metals with nets).

\section{Analytical methods}

The quantitative data is described with simple descriptive statistics and represented with frequency distribution tables, pie charts and graphs. Relational links are created within the variables using mean comparisons. The analysis did not include rigorous methods of causeeffect or correlational relationship, which seeks to make inferences about the population and forward prediction. The objective of investigating the possible electricity expenditure burden on households who depend on certain types of windows, was, however, still achievable with simple mean comparison and frequency distribution analysis.

To complement the descriptive statistics from the quantitative data, quotes generated from the qualitative data through content analysis were used. Various themes were developed based on the relevant variables available in the quantitative data. The themes convey narratives and discussions that address the objective of the study. The themes also inform the qualitative analysis and integration. The researchers undertook first and second cycle coding in an exploratory coding method by identifying and representing interested views of the participants. This approach is preferred because it seeks to assign codes based on what the researchers assume to be present in the data (Creswell, 2007). In the transcripts, holistic and hypothetical types of coding were done to represent the views of the participants and the researchers' hypothetical presumptions. 
Window design selection and energy consumption implications for residential buildings in Ghana: A behavior-change analysis of Ga East and Awutu Senya East Municipalities

\section{Discussions}

The analysis and discussion of the results dwell on both the quantitative and qualitative techniques, which are complementary in nature. In a non-comparative approach, the results on the central objective of the paper are mostly discussed around the two municipalities (GEM and ASEM) and around the settlement classifications in the municipalities. This approach is adopted instead of a comparison because there are homogenous sets of respondents in both municipalities.

\section{Evidence of the shift from traditional windows to new window designs among households in GEMand ASEM}

Households in the two municipalities dwell in different kinds of units ranging from owned semi-detached and separate houses to rented compound houses, flats/apartments, kiosks/containers or uncompleted buildings. The ownership status of these dwelling units coupled with their structural designs often determines the kinds of window systems that are incorporated. The data gathered reveal that most electrified households in GEM dwell in compound houses and separate houses (35\% and 39\% respectively in First Class households; $64 \%$ and $28 \%$ respectively in Second Class households; and $40 \%$ and $33 \%$ respectively in Third Class households) as shown in Figure 2. The predominant window types used within these dwelling units across all three-settlement classes, is the louvre blade windows (Figure 3). Of significant note from the data is the decreasing use of wooden windows among the households in GEM (9\% for third- and first-class households and 12\% for second class households) while glazed (sliding glass) windows is gaining ground especially among first and second class households. 


\begin{tabular}{|c|c|c|c|c|}
\hline \multirow{6}{*}{ 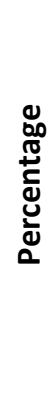 } & \multirow{6}{*}{$\begin{array}{r}100 \% \\
90 \% \\
80 \% \\
70 \% \\
60 \% \\
50 \% \\
40 \% \\
30 \% \\
20 \% \\
10 \% \\
0 \%\end{array}$} & & & \multirow{3}{*}{ 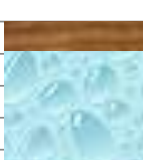 } \\
\hline & & & \multirow{2}{*}{$6 x+2<9$} & \\
\hline & & & & \\
\hline & & & 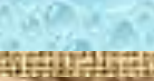 & 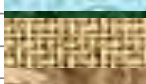 \\
\hline & & & & \\
\hline & & 1st Class & 2nd Class & 3rd Class \\
\hline \multicolumn{2}{|c|}{ Uncompleted building } & 3.33 & 0 & 8.889 \\
\hline \multicolumn{2}{|c|}{ Quarters attached to office } & 0.77 & 0 & 0 \\
\hline \multicolumn{2}{|c|}{ Kiosk/Container } & 3.08 & 0 & 0 \\
\hline \multicolumn{2}{|c|}{ Compound house } & 34.87 & 64 & 40 \\
\hline \multicolumn{2}{|c|}{ Flat/Apartment } & 13.59 & 0 & 2.22 \\
\hline \multicolumn{2}{|c|}{ semi-detached } & 4.87 & 8 & 15.56 \\
\hline \multicolumn{2}{|c|}{ Separate House } & 39.49 & 28 & 33.33 \\
\hline
\end{tabular}

Figure 2: Dwelling units of electrified households in GEM Source: ISSER SoE Survey in GEM, 2014
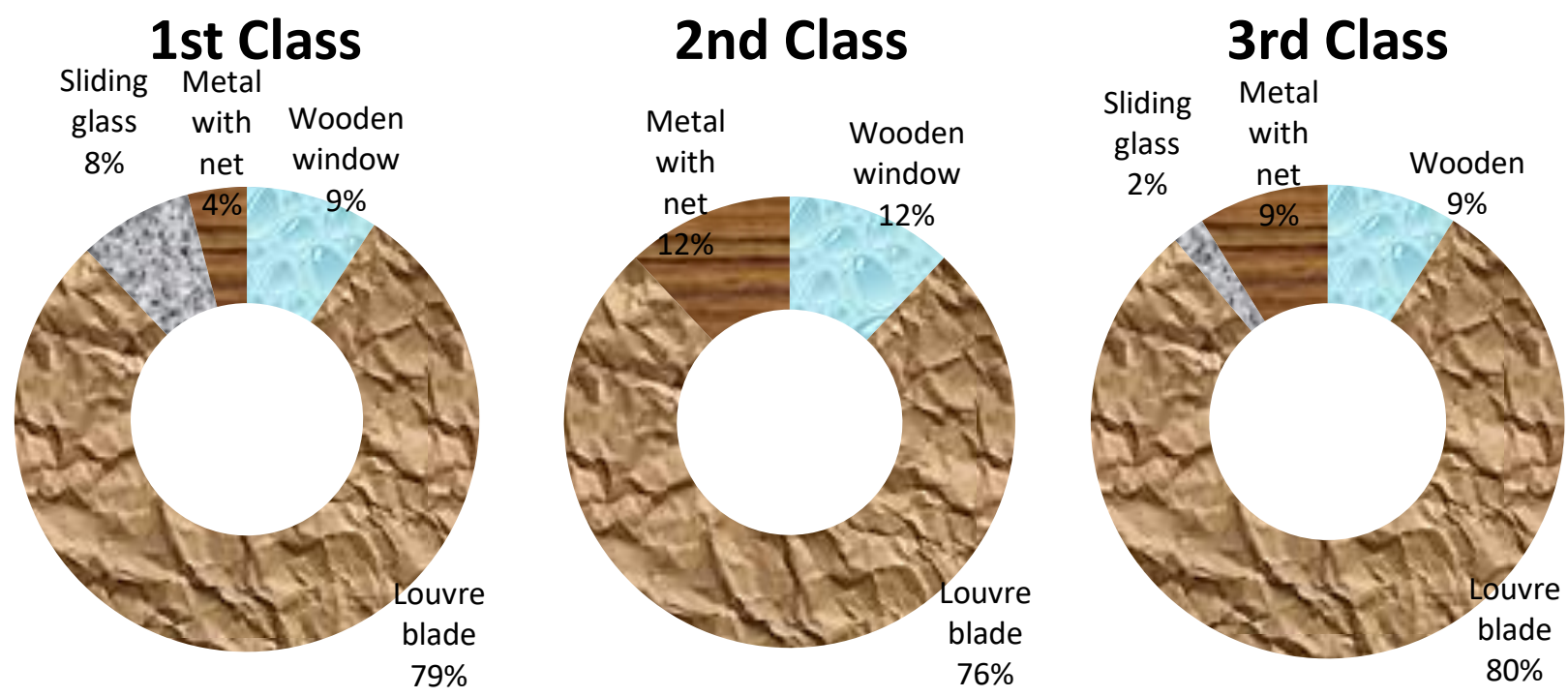

Figure 3: Window types within dwelling units in electrified households in GEM Source: ISSER SoE Survey in GEM, 2014

The data also revealed that most electrified households in ASEM live in separate houses (51\% of first-class households; $44 \%$ of second-class households and $40 \%$ of third-class households) as shown in Figure 5. The window type used mostly in these dwelling units is the louvre blade windows (Figure 6). It is, however, evident from the data that fewer proportion of households across all three classes of settlements are using the traditional wooden window while higher 
Window design selection and energy consumption implications for residential buildings in Ghana: A behavior-change analysis of Ga East and Awutu Senya East Municipalities

proportions are using the new designs like the louvre blades and glazed windows. This phenomenon represents significant shift from the use of traditional windows to new window designs in the two municipalities. More evidence of the shift to new window designs is revealed further in the section where respondents noted having shifted from a particular window design they have used in the past.

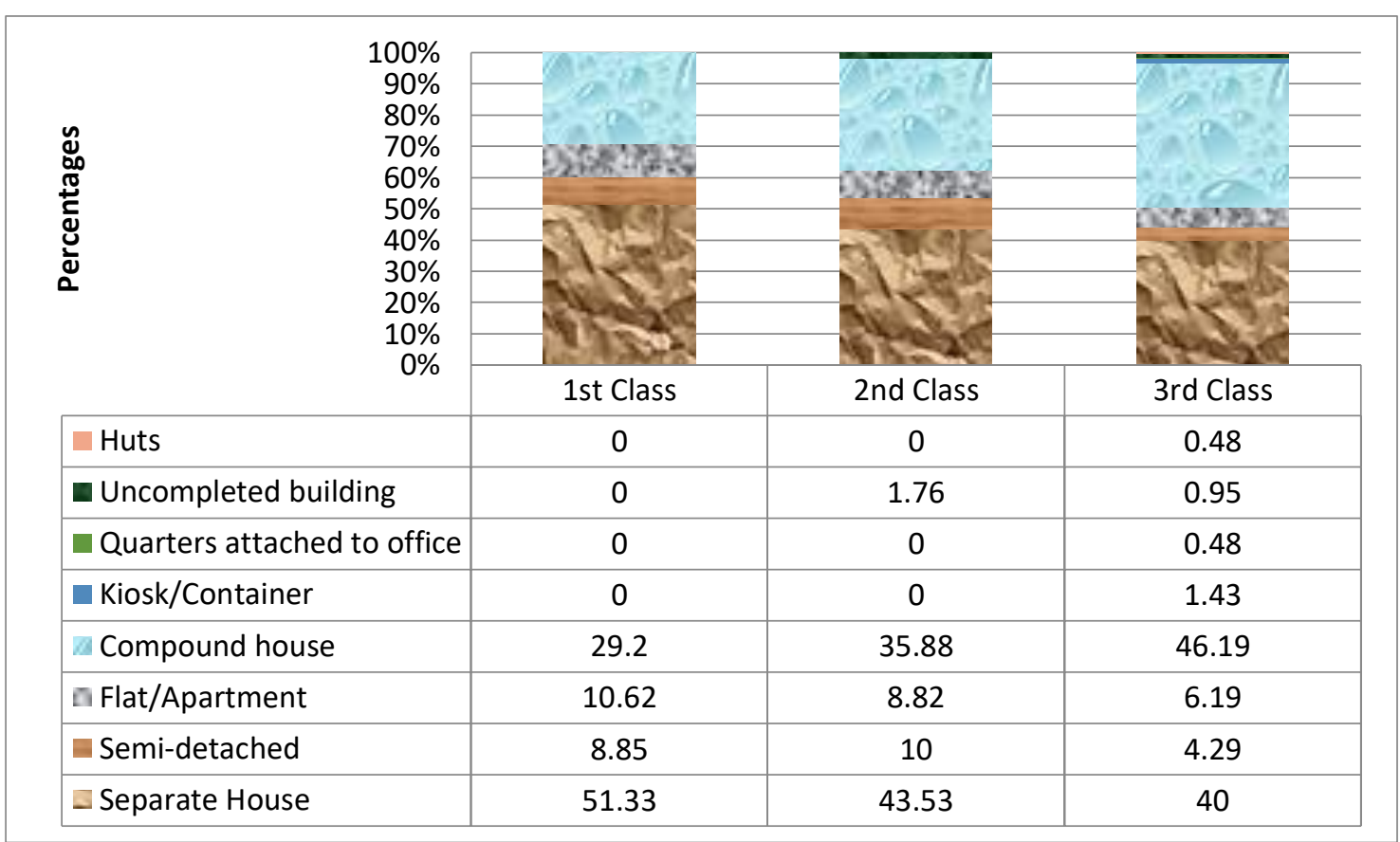

Figure 4: Dwelling units of electrified households in ASEM

Source: ISSER SoE Survey in ASEM, 2014 

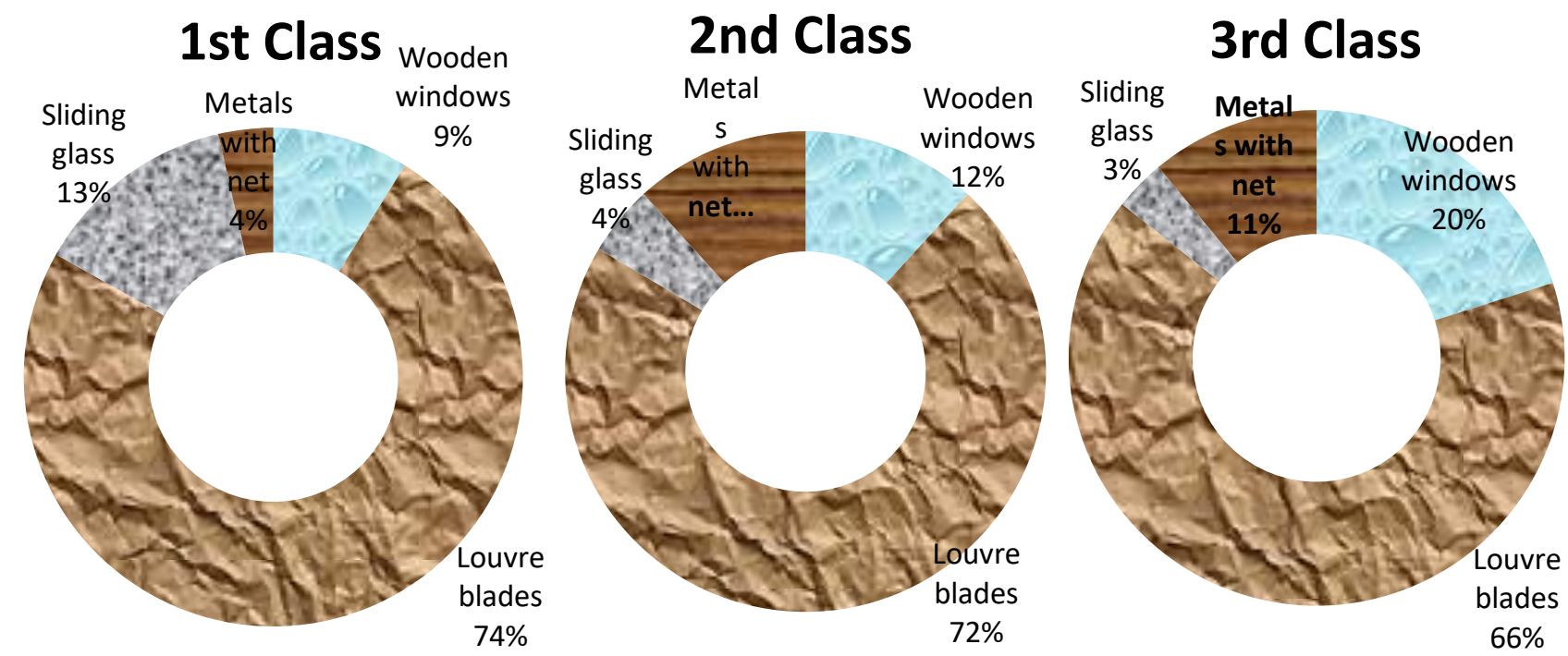

Figure 5: Window types within dwelling units in electrified households in ASEM Source: ISSER SoE Survey in ASEM, 2014

Evidence from the in-depth interviews corroborates the change in preference for modern window designs over the years among households in the municipalities. A household member who currently uses glazed windows in her house gave an overview of the window type she had in her place of habitation in the past compared to present.

At my former place I was using louvre blade windows. That was my own house, the one I built myself. Some parts, I was using the wooden windows, yes, some of the rooms have wooden windows. However, the other part of the house has louvre blades. Now in my son's house, we are using sliding glazed windows. (An elderly female respondent ' $E$ ' in a second-class community in GEM, 2014).

Three other glazed window users confirmed having moved on from using glass louvre blades to the glazed window types in recent times. One of such respondents explained as follows:

I was staying in a government bungalow, which was fitted with louvre blades. Currently, I am using a mix of louvre blades and then the sliding glazed windows in my own house. (An adult male respondent 'A' in a first-class community in ASEM, 2014). 
Window design selection and energy consumption implications for residential buildings in Ghana: A behavior-change analysis of Ga East and Awutu Senya East Municipalities

\section{Underpinning factors for the shift from traditional windows to the new window designs}

In the era of modernisation coupled with rapid technological advancement, many people are influenced by what they see around them. Empirically, the shift to new window designs in GEM and ASEM is motivated more by aesthetic reasons than energy efficiency. Among the various reasons assigned to the shift from traditional windows and louvre blades to the new glazed window designs, energy issues are never mentioned. Households in the two municipalities adopt new window designs for aesthetic purposes. Such decisions are underpinned by environmental and personal factors as postulated by the Social Cognitive Theory.

One of the in-depth interviewees voiced out his thoughts when asked about the factors underlining his shift to a new window design as follows:

Modernisation, you know, you look at what is prevailing in the community. When we were moving in (to our new place), I realized that almost all the structures, people were using the glazed sliding windows. Therefore, I felt that, I have to also go with modernization. So, we replaced the louvre blades in the frontage, the hall, the master bedroom that is facing the roadside with the glazed sliding windows. (An adult male respondent ' $A$ ' in a first-class community in ASEM, 2014).

Views from two other glazed window users who were interviewed lend support to the prioritization of aestheticism in the behavioral choice of glazed window type(s) in contemporary times.

This window type (glazed window) is appealing. If you look around this neighborhood, that is the most common window type you will find. Everybody is fixing it... lots of people have it. (An adult male respondents ' $\mathrm{G}$ ' in a first-class community in GEM, 2014).

It (glazed window) is nice. When you fix the glazed sliding windows in your house, it makes the house more appealing than if you fix the louvre blades. But if you use the sliding glass throughout for the whole building for all the rooms, it's a cost. (An adult male respondent ' $\mathrm{B}$ ' in a second-class community in ASEM, 2014). 
From the data, energy issues surface very minimally as part of the reasons for the shift from traditional window designs to the modern ones. In the process of undertaking the qualitative interviews, only one louvre blades window user cited an energy issue as the reason for her shift from a traditional wooden window to louvre blades.

I prefer louvre blades to the wooden, which I was using at my former residence. With the louvres, the window sizes are big so when I open them more air comes into the rooms. Therefore, I don't use fan often. (An elderly female respondent ' $F$ ' in a secondclass community in GEM, 2014).

Another principal reason people assign to the shift from traditional window designs to the glazed one especially, is the affordability by households that make the shift. It is clear from the data that those who dwell in separate houses or semi-detached houses with glazed windows are often found in First Class settlements while those who dwell in compound houses and uncompleted buildings, kiosks or containers often use the traditional wooden windows. According to one of the respondents who currently uses only open metal wire with net:

Life is difficult here..., cost of living is high and there is no money so I could only afford this house and this metal wire and the net, which were here before I moved in. (An adult female respondent ' $D$ ' in a third-class community in ASEM, 2014)

One wooden window user also reiterated that income does influence the choice of window type one installs. She observed that:

When I moved to this house, I didn't have enough money to change this window type to a different one like glazed one. If I had enough money, I would have changed this to a different type immediately I came here, but I don't have that kind of money now. (An adult female respondent ' $C$ ' in a second-class community in GEM, 2014)

From the above emerging evidence, it is clear that individual behavior changes involving the use of different window types are largely influenced by aesthetic reasons and to some extent, income status of the household. Little is said about energy efficiency issues as the reasons for shifting to a particular window type. Despite the geographical locational advantage of GEM and ASEM - at the coastal belt where there is free flowing sea breeze - many land owners and 
Window design selection and energy consumption implications for residential buildings in Ghana: A behavior-change analysis of Ga East and Awutu Senya East Municipalities

estate developers construct buildings without seeking enough technical advice in order to take advantage of the cool breeze from nature. Corroborating this argument is the statement from a glazed windows user:

My decision was not influenced by any professional advice. Just looking around the area I live I felt that everybody was using the glazed sliding windows, so I decided to replace the louvre blades with the sliding windows. However, I must say that I have regretted doing that because, during daytime I am compelled to switch on my lights because the room is often dark without the lights. (An adult male respondent 'A' in a first-class community in ASEM, 2014).

Evidence from this paper shows that individuals do not necessarily consider the consequences of their decisions before adopting glazed windows. This could be explained by the environmental competence and learned helplessness theories in that there is widespread "environmental incompetence" among households where they are either unaware of their ability or they completely lack the ability to both understand and negotiate the environment in a meaningful way. The "environmental incompetence" and "learned helplessness" of households in their decisions to shift to environmental unfriendly window types is because of lack of specific guidelines in the National Building Regulations of Ghana to dictate the specific environmentally friendly materials to use.

\section{Implications of the shift from traditional to new window designs}

It is evident from both the qualitative and quantitative survey results that different window types have implications on energy consumption efficiency in the two municipalities. From the qualitative study, those who have shifted from louvre blade windows to glazed windows have noted comparatively that they consume more energy and spend more money on energy bills than when they were using louvre blades. 
Ghana Journal of Geography Vol. 12 (2), 2020 pages 25- 61

Three glazed window users recounted their assessments below:

The glazed sliding window is making me spend more. Because I can tell you that our electricity bill has gone up considerably compared to the period, we were using the louvre blades in the past. (An adult male respondent ' $\mathrm{A}$ ' in a first-class community in ASEM, 2014).

If you live in the sliding glass, you will know that it traps heat. It shows that it is something if you fix, you will be forced to use AC. Thus, I have realized that, if I am not careful, the way my electricity bill will go up, it won't be easy at all (An elderly female respondent ' $E$ ' in a second-class community in GEM, 2014).

There is serious heat with the sliding glazed window especially when lights are out, the heat becomes unbearable sometimes (An adult female respondent ' $\mathrm{A}$ ' in a second-class community in GEM, 2014).

On the contrary, some louvre blade users expressed the ventilation potentials of the louvre blade system relatively. According to one louvre blade window user;

I prefer this one (louvre blade). With the louvre [blade windows], the window sizes are big so when I open them more air comes into the rooms. (An elderly female respondent ' $F$ ' in a second-class community in GEM, 2014).

From the quantitative data, it is revealed that households with glazed windows in their dwelling units depend more on fans and air conditioners (AC) while dwelling units with the louvre blade and traditional wooden windows depend more on fan and the natural ventilation system respectively. In GEM, almost $23 \%$ of first-class households with glazed sliding windows in their dwelling units use $\mathrm{AC}$ as their main ventilation system (Figure 6). In ASEM, the proportion of first-class households with glazed windows in their dwelling units using AC as their main ventilation system is about $27 \%$ (Figure 7). 
Window design selection and energy consumption implications for residential buildings in Ghana: A behavior-change analysis of Ga East and Awutu Senya East Municipalities

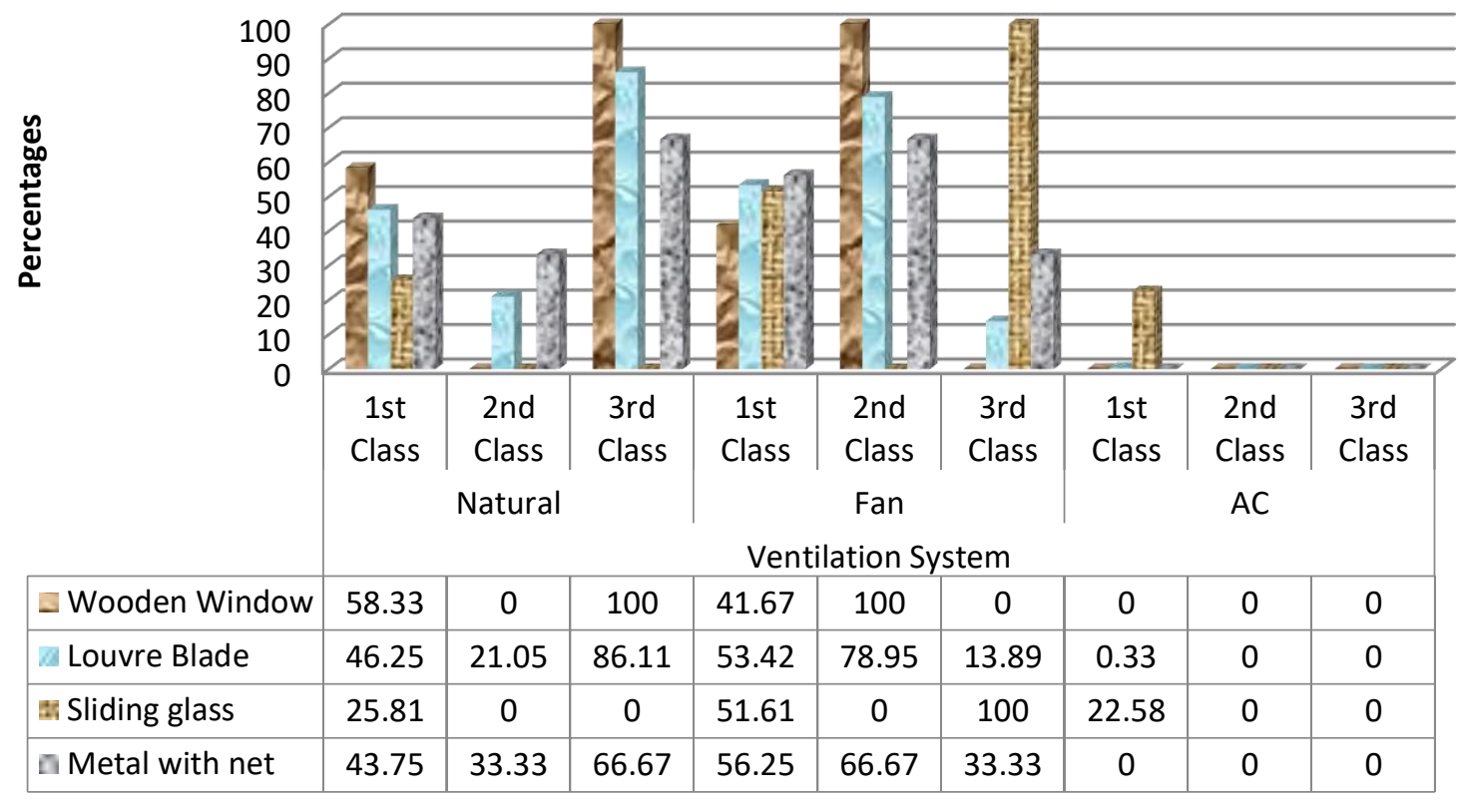

Figure 6: Window type in the dwelling unit vis-à-vis ventilation system (\%) being used in GEM Source: ISSER SoE Survey in GEM, 2014

\begin{tabular}{|c|c|c|c|c|c|c|c|c|c|c|}
\hline \multirow{12}{*}{\multicolumn{2}{|c|}{$\begin{array}{r}90 \\
80 \\
70 \\
60 \\
50 \\
40 \\
30 \\
20 \\
10 \\
0\end{array}$}} & & & & & & & & & \\
\hline & & & & & & & & & & \\
\hline & & & & 27 & 8 & ty & & & & \\
\hline & & & & 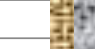 & 1 & 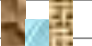 & $\Rightarrow$ & & & \\
\hline & & & - & & 30 & & -2 & & & \\
\hline & & $=5$ & 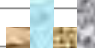 & & 4 & & 50 & 需 & & \\
\hline & & 24,7 & dete & 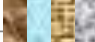 & $N$ & tit & 24 & 4 & & \\
\hline & & & 48 & $3 t$ & Z & $=-\frac{3}{25}$ & $N$ & 辈 & & \\
\hline & & $1 s t$ & 2nd & $3 r d$ & $1 s t$ & 2nd & $3 r d$ & $1 s t$ & 2nd & $3 r d$ \\
\hline & & Class & Class & Class & Class & Class & Class & Class & Class & Class \\
\hline & & & Natura & & & Fan & & & $A C$ & \\
\hline & & & & & Ven & lation $\$$ & tem & & & \\
\hline & Wooden Window & 30 & 25 & 42.86 & 70 & 75 & 57.14 & 0 & 0 & 0 \\
\hline & Louvre Blade & 33.33 & 45.1 & 37.96 & 66.67 & 54.9 & 62.04 & 0 & 0 & 0 \\
\hline & Sliding glass & 26.67 & 25 & 71.43 & 46.67 & 75 & 28.57 & 26.67 & 0 & 0 \\
\hline & Metal with net & 50 & 80 & 78.26 & 50 & 20 & 21.74 & 0 & 0 & 0 \\
\hline
\end{tabular}

Figure 7: Window type in the dwelling unit vis-à-vis ventilation system (\%)used in ASEM Source: ISSER SoE Survey in ASEM, 2014

These findings from the quantitative data corroborate the qualitative findings that households with glazed window in their dwelling units spend more on energy due to their window types compared to households with other window types in their dwelling units. About $50 \%$ of 
households with glazed windows in their dwelling units in first-class settlements in the municipalities under study were affirmative when they were asked as to whether they think they spend more on energy due to their window types they use compared to other window type(s) users (Table 3).

Further evidence from the data shows that even though the sampled households with glazed windows in the dwelling units constitute only $9.15 \%$ of the total first -class households, they consume a monthly total of about $13,833.33 \mathrm{kWh}$ of electricity in 2013 while the sampled households with louvre blades windows in their dwelling units, which constitutes about $78 \%$ of the total first class households in the two municipalities consume a monthly total of about $67,012.12 \mathrm{kWh}$ of electricity in 2013 (Table 4). In percentage terms, every $1 \%$ of louvre blades windows users consume about $862.11 \mathrm{kWh}$ of electricity while every $1 \%$ of glazed windows users consume about $1511.84 \mathrm{kWh}$ of electricity. Traditional wooden window users, however, consumed monthly about $4203 \mathrm{kWh}$ of electricity, having also constituted about $9.15 \%$ of the total first-class households in the two municipalities. It is also evident from Table 4 that firstclass households using glazed windows with fans and ACs consume lots of energy.

Table 3: Expenditure on energy vis-à-vis window types

\begin{tabular}{lllll}
\hline Compared to other window types, do & \multicolumn{4}{c}{ Window Type } \\
\cline { 2 - 5 } $\begin{array}{l}\text { you think you spend more on energy } \\
\text { due to your window type? }\end{array}$ & Wooden & Louvres & Glazed & Other \\
\hline Don't know & 10.87 & 8.18 & 4.35 & 20.00 \\
\hline Yes & 2.17 & 4.86 & 50.00 & 15.00 \\
\hline No & 86.96 & 86.96 & 45.65 & 65.00 \\
\hline Total & 100 & 100 & 100 & 100 \\
\hline
\end{tabular}

Source: ISSER SoE Survey in ASEM and GEM, 2014 
Window design selection and energy consumption implications for residential buildings in Ghana: A behavior-change analysis of Ga East and Awutu Senya East Municipalities

Table 4: Window type vis-à-vis ventilation system and the total monthly electricity consumed $(\mathrm{kWh})$ for First Class electrified households

\begin{tabular}{|c|c|c|c|c|c|c|}
\hline \multirow[t]{2}{*}{ Window type } & \multirow[t]{2}{*}{ Freq. } & \multirow{2}{*}{$\begin{array}{l}\% \text { who have } \\
\text { window type }\end{array}$} & \multicolumn{3}{|c|}{ Ventilation system } & \multirow[t]{2}{*}{ Total } \\
\hline & & & Natural & Fan & $\mathrm{AC}$ & \\
\hline Wooden & 46 & 9.15 & 1706.06 & 2496.97 & & 4203.03 \\
\hline Louvres & 391 & 77.73 & 28077.27 & 38843.94 & 90.91 & 67012.12 \\
\hline Glazed & 46 & 9.15 & 2045.45 & 6560.61 & 5227.27 & 13833.33 \\
\hline Other & 20 & 3.98 & 1318.18 & 2242.42 & & 3560.61 \\
\hline
\end{tabular}

Source: ISSER SoE Survey in ASEM and GEM, 2014

An important inference from the findings is that people's preference for window types that are often used in dwelling units is influenced by changes that are happening around them as well as personal aesthetic aspirations. Evidently, prior to the making of such preferences, the consequences are often unknown to the decision makers. This iterates the theory of "learned helplessness" of individuals such that they are unable to control a situation (like preference for a particular window type) in which they are involved and which they cannot avoid. In both municipalities, many people are shifting to new window designs without much understanding of the energy repercussion. According to the head of Energy and Climate Change division at the Energy Commission of Ghana, single glazing, which is gaining much popularity among Ghanaian homes, is becoming a huge hurdle in the quest for energy efficiency. What is happening is that many glazed windows are being fixed and many air-conditioners are being installed because single-glazing windows contribute to warmer temperatures ${ }^{9}$.

In the midst of the current electricity supply challenges and the high electricity tariffs, a significant proportion of households in Ghana still desire to live in dwelling units with sliding glazed windows, which according to the evidence discussed above, trap heat and contribute to warmer temperatures. To the "significant proportion" who values the "beauty" of the new glazed system above anything else, going back to the louvres is never an option.

\footnotetext{
${ }^{9}$ Available at http://www.lamudi.com.gh/journal/540/
} 
According to one glazed window user,

If I get the same type (sliding glazed window) I will use in the future because it appeals to me, I like it so much (An adult male respondent ' $\mathrm{B}$ ' in a second-class community in ASEM, 2014).

Finally, to the many who dream of living in comfortable houses when they get an improvement in their household income, glazed windows are the most befitting option. These raise serious questions concerning effectiveness of the NBR of Ghana towards ensuring that energy efficiency for buildings take root in the country. One respondent exclaimed,

If the opportunity comes, yes, I will change the window type to the sliding glazed window type and go look for some AC and install in it so that I can enjoy some better air. It doesn't allow in dust and always your room will be clean (An adult female respondent ' $E$ ' in a second-class community in ASEM, 2014).

\section{Conclusions and policy implications}

Through qualitative and quantitative data analysed, the paper has unearthed that there has been a shift from the traditional windows to new window designs (louvre and glazed windows) in GEM and ASEM. Electrified households in GEM and ASEM predominantly use louvre blade windows in their dwelling units. However, the use of sliding glazed windows is on the rise. A significant proportion of glazed window users in first -class communities in the two municipalities consume more energy and in turn spend more on energy compared to other window types users because, they depend more on fans and $\mathrm{AC}$ than the natural crossventilation strategy. Evidently, more people desire to shift to the glazed windows because of their perceived aesthetic values without reflecting on the negative consequences on energy consumption and climate change.

Currently, the existing National Building Regulations of Ghana are somewhat misaligned with energy efficiency requirements. Building plans are not thoroughly scrutinized by the appropriate local authorities to delineate their compatibility with energy efficiency requirements. Consequently, architectural designs are approved and built regardless of the energy performance of the building. The findings of the study drum home the need to re- 
Window design selection and energy consumption implications for residential buildings in Ghana: A behavior-change analysis of Ga East and Awutu Senya East Municipalities

examine the existing building codes in order to make provisions for energy efficiency requirements. Such re-examination should take into consideration, aesthetic aspirations versus energy efficiency performance outcomes of buildings.

Clearly, from the data, many people have limited "information" to guide the "decision" they are making concerning the window type(s) to install in their dwelling units. They are often driven by what they see in the environment and guided by their personal instincts. The financial and environmental impacts of their preferences are often unknown. Either the right institutions to consult are non-existent or they exist but lack control or are under capacitated to carry out their responsibilities adequately. The technical departments in the two municipalities should be strengthened to play their integral role on the energy efficiency agenda for their built environment.

\section{Funding}

We deeply appreciate the support of UK aid from the UK Department for International Development (DFID), the Engineering \& Physical Science Research Council (EPSRC) and the Department for Energy \& Climate Change (DECC), for funding the project [Grant Ref: EP/L002620/1] from which this article was written.

\section{References}

Abeberese, A. B., Ackah, C., \& Asuming, P. (2017). Productivity Losses and Firm Responses to Electricity Shortages: Evidence from Ghana (No. E-33305-GHA-1). [online]https://www.theigc.org/wp-content/uploads/2018/06/Abeberese-et-al-2017Workingpaper.pdf (Accessed: 15/11/2016).

AfDB-ERERA (2019). Comparative analysis of electricity tariffs in ECOWAS member countries. African Development Bank Group and ECOWAS Regional Electricity Regulatory Authority. 2019. [online] https://africa-energy portal.org/sites/default/files/2019-12/Electricity\%20Tariffs\%20Study\%202019.pdf (Accessed: 15/11/2016). 
Agyeiwaah, E. (2019). Exploring the relevance of sustainability to micro tourism and hospitality accommodation enterprises (MTHAEs): Evidence from home-stay owners. Journal of Cleaner Production, 226, 159-171. https://doi.org/10.1016/j.jclepro.2019.04.089

Ali, M. M. (2008). Energy efficient architecture and building systems to address global warming. Leadership and management in engineering, 8(3), 113-123.

Armstrong, M. and Burrows, J. (2008). Window glazing study at CCHT shows good results. Solplan Review, no. 143, pp.2

Baker, P., Curtis, R., Kennedy, C., \& Wood, C. (2010). Thermal performance of traditional windows and low-cost energy-saving retrofits. APT Bulletin, 41(1), 29-34.

Bandura, A. (1986). Social Foundations of Thought and Action. Englewood Cliffs, New Jersey: Prentice-Hall.

Bawakyillenuo, S., Agbelie, I. S. K. 2015. Awutu Senya East Municipality State of Energy Report 2014, ISSER, University of Ghana, Legon.

Bawakyillenuo, S., Agbelie, I. S. K. 2015. Ga East Municipality State of Energy Report 2014, ISSER, University of Ghana, Legon.

Campbell, D. (1981). "Microenvironments of the Elderly" in F. J. Berzhorn and D. E. Schafer (eds) The Dynamics of Aging. Boulder, CO: Westview Press, 1981.

CASA ASSOCIATI, (2012). Africa adaptation Programme on Climate Change. Integrating Climate Change and Disaster Risk Reduction in Physical Development - Review ofGhana Building Code.

Chusak, L., Daiber, J. \& Agarwa, R. (2012). Increasing energy efficiency of HVAC systems of buildings using phase change material. International Journal of Energy and Environment, 3(5), 667-686.

Creswell, J. W. (2007). Qualitative inquiry and research design: Choosing among five approaches (2nd ed.). Sage Publications, Inc.

Department of Trade and Industry (2003). Our Energy Future -Creating a Low Carbon Economy, HMSO, London. Referenced in: Heather Chappells \& Elizabeth Shove (2005) Debating the future of comfort: environmental sustainability, energy consumption and the indoor environment, Building Research \& Information, 33(1), 32-40

Dippenaar, M. (2018). The role of tax incentives in encouraging energy efficiency in the largest listed South African businesses. South African Journal of Economic and Management Sciences, 21(1), 1-12. https://sajems.org/index.php/sajems/article/view/1723/1106 
Window design selection and energy consumption implications for residential buildings in Ghana: A behavior-change analysis of Ga East and Awutu Senya East Municipalities

Elleh, N. (1996). African architecture: evolution and transformation. McGraw-Hill Professional Publishing.

Energy Commission. (2020). National Energy Statistics 2000-2019. Strategic Planning and Policy Directorate. Accra, Ghana

Fatoki, O. (2019). Environmental Sustainability Practices of Immigrant-Owned Small and Medium Enterprises in South Africa. European Review Of Applied Sociology, 11(17), 2743. https://doi.org/10.1515/eras-2018-0009

Fishbein, M. \& Ajzen, I. (1975). Belief, Attitude, Intention and Behavior: An Introduction to Theory and Research. Reading, MA: Addison-Wesley.

Ghana Statistical Service (2014a). 2010 Population and Housing Census. District Analytical Report. Awutu Senya East Municipality.

Ghana Statistical Service (2014b). 2010 Population and Housing Census. District Analytical Report. Ga East Municipality.

Ghana Statistical Service. (2019). Ghana Living Standards Survey Round 7 (GLSS 7). Main Report. Ghana Statistical Service. Accra-Ghana.

Global Buildings Performance Network (GBPN) (2013). Building for our Future: The Deep Path for Closing the Emissions Gap in the Building Sector (Paris: June 2013), [online] http://www.gbpn.org/sites/default/files/06/BuildingsForOurFurture_Low.pdf (Accessed on 15/5/2019).

Gouws, P. ., Brent, A. ., \& Pierce, W. . (2012). The contribution of energy efficiency towards the success of industrial organisations in South Africa. South African Journal of IndustrialEngineering, 23(5), 57-65.

Guy, S. (2002). Sustainable Buildings: Meanings, Processes, Users. Built Environment, 28 (1), 4-10.

Gyimah, K. A. \& Tellow, D. (2014). Achieving energy efficiency and aesthetics through windows in the Tropics. JENRM, 1(1), 29-35. Hermes, M. W. (2006). Energy saving potentials from the use of modern window systems in Europe. PVC study on windows. [Online] http://www.pvcinfo.be/bestanden/Hermes\%20Study\%20\%20PVC\%20windowsEnglish.p df (Accessed on 12/11/2015).

Hermes, M. W. (2006). Energy saving potentials from the use of modern window systems in $\begin{array}{llll}\text { Europe study on windows. } & \text { [online] }\end{array}$ http://www.pvcinfo.be/bestanden/Hermes\%20Study\%20\%20PVC\%20windowsEnglish.pdf (Accessed on 12/11/2015) 
Kantrowitz, M. (1984). Energy Efficient Buildings: An Opportunity for User Participation.Journal of Architectural Education, 37(3/4), 26-31.

Kaplan, S. (1983). "Person-Environment Compatibility" in Stokols, D. (ed) Theories ofEnvironment and Behavior: New Directions, Environment and Behavior, May 1983.

Kelly, M. J. (2010). Energy efficiency, resilience to future climates and long-term sustainability: the role of the built environment. Philosophical Transactions: Mathematical, Physical and Engineering Sciences, 368(1914), 1083-1089.

Kempton, W., Darley, J.M. \& Stern, P.C. (1992). Psychological research for the new energy problems: Strategies and opportunities. American Psychologist, 47(10), 1213-1223.

Koranteng, C. (2010). Energy performance of office buildings in Ghana. Journal of Science and Technology (Ghana), 30(2).

Krioukov, A., Dawson-Haggerty, S., Lee, L., Rehmane, O., \& Culler, D. (2011). A living laboratory study in personalized automated lighting controls. In Proceedings of thethird ACM workshop on embedded sensing systems for energy-efficiency in buildings (pp. 16). ACM.

Laban, M. D. \& Folić, R. J. (2014). Energy Efficiency of Industrially Made BuildingsInfluenced by thermal properties of facades. Thermal Science, 18(2), 615-630

Leaman, A. \& Bordass, B. (2007). Are users more tolerant of 'green' buildings? BuildingResearch \& Information, 35(6), 662-673.

Maçka, S., \& Yasar, Y. (2011). The Effects of Window Alternatives on Energy Efficiency and Building Economy in High-Rise Residential Buildings in Cold Climates. Gazi University Journal of Science, 24(4), 927-944.

Muneer, N., Abodahab, N., Weir, G., \& Kubie, J. (2000). Windows in Buildings, Thermal, Acoustic, Visual and Solar Performance. Architectural Press, Oxford, 6-10 (2000).

Parasonis, J. \& Keizikas, A. (2010). Possibilities to reduce the energy demand for multi-storey residential buildings, in the $10^{\text {th }}$ International Conference "Modern Building Materials,Structures and Techniques": Selected papers, Vol II. VGTU: Technika, 989993.

Parasonis, J., Keizikas, A., Endriukaitytė, A. \&Kalibatienė, D. (2011). Architectural solutions to increase the energy efficiency of buildings. Journal of Civil Engineering and Management, 18(1): 71-80.

Raloff, J. (1988). Energy Efficiency: Less Means More. Science News, 133(19) pp. 296-298.

REN21 (2014). ECOWAS Renewable Energy and Energy Efficiency Status Report (Paris: REN21 Secretariat) ISBN 978-3-9815934-2-6. 
Window design selection and energy consumption implications for residential buildings in Ghana: A behavior-change analysis of Ga East and Awutu Senya East Municipalities

Rohracher, H. \& Ornetzeder M. (2002). Green Buildings in Context: Improving Social Learning Processes between Users and Producers. Built Environment, 28 (1) 73-84.

Schreckenbach, H. (1981), "Construction Technology for a Developing Country", GTZ Publications, pp 21-72.

Seligman, M. E. (1975). Helplessness: On depression, development, and death. WH Freeman/Times Books/Henry Holt \& Co.

Silverstein, S. (2007). A study of glazing design for energy savings in sustainable construction. Cornell University School of Civil and Environmental Engineering. [Online] https://courses.cit.cornell.edu/engrwords/final_reports/Silverstein_report_rev.pdf

(Accessed on 12/11/2015).

Stojanović, B. V., Janevski, J. N., Mitković, P. B., Stojanović, M. B., \& Ignjatović, M. G. (2014). Thermally activated building systems in context of increasing building energy efficiency. Thermal Science, 18 (3), 1011-1018.

Swithenbank, M. (1969). An Ashanti fetish house, Ghana University press

United Nations Development Programme (UNDP) (2010). Promoting energy efficiency in building: lessons learned from international experience. (Environment and Energy). [online]https://www.thegef.org/gef/sites/thegef.org/files/publication/EEBuilding_WEB.p df (accessed: 24/10/2015)

UN-HABITAT (2016). Urbanization and development: Emerging Futures. World cities Report 2016. UN-HABITAT

World Bank (2019). World Development Indicators (WDI). The World Bank Group. Washington, DC. World Bank.

World Business Council for Sustainable Development (WBCSD) (2009). Energy Efficiency in Buildings: Business realities and opportunities. Facts \& Trends, Summary Report. [Online] http://www.wbcsd.org/pages/edocument/edocumentdetails.aspx?id=13559 (Accessed: 24/10/2015)

WEC, (2013). World Energy Resources. 2013 Survey. World Energy Council.

Yaşar, Y., Pehlevan, A., Maçka, S. (2009). "Comparing the energy performance of double glazed Windows with different low-e coatings according to Turkish Climate Regions", $4^{\text {th }}$ International Building Physics Conference, 15-18 June, İstanbul, Turkey. 